\title{
A GIS-based approach in drainage morphometric analysis of Kanhar River Basin, India
}

\author{
Praveen Kumar Rai • Kshitij Mohan • \\ Sameer Mishra · Aariz Ahmad • Varun Narayan Mishra
}

Received: 8 July 2014/ Accepted: 16 October 2014/Published online: 7 November 2014

(c) The Author(s) 2014. This article is published with open access at Springerlink.com

\begin{abstract}
The study indicates that analysis of morphometric parameters with the help of geographic information system (GIS) would prove a viable method of characterizing the hydrological response behaviour of the watershed. It is also well observed that remote sensing satellite data is emerging as the most effective, time saving and accurate technique for morphometric analysis of a basin. This technique is found relevant for the extraction of river basin and its stream networks through ASTER (DEM) in conjunction with remote sensing satellite data (Landsat etm+, 2013 and georeferenced survey of Indian toposheet, 1972). In this study, Kanhar basin a tributaries of Son River has been selected for detailed morphometric analysis. Seven sub-watersheds are also delineated within this basin to calculate the selected morphometric parameters. Morphometric parameters viz; stream order, stream length, bifurcation ratio, drainage density, stream frequency, form factor, circulatory ratio, etc., are calculated. The drainage area of the basin is $5,654 \mathrm{~km}^{2}$ and shows sub-dendritic to dendritic drainage pattern. The stream order of the basin is mainly controlled by physiographic and lithological conditions of the area. The study area is designated as seventhorder basin with the drainage density value being as $1.72 \mathrm{~km} / \mathrm{km}^{2}$. The increase in stream length ratio from lower to higher order shows that the study area has reached a mature geomorphic stage.
\end{abstract}

P. K. Rai $(\varangle) \cdot$ K. Mohan · S. Mishra · A. Ahmad Department of Geography, Banaras Hindu University, Varanasi 221005, UP, India

e-mail: rai.vns82@gmail.com

V. N. Mishra

Department of Physics, Indian Institute of Technology (BHU), Varanasi 221005, UP, India
Keywords Drainage morphometry - Kanhar basin . Watershed · DEM · GIS

\section{Introduction}

Morphometry is the measurement and mathematical analysis of the configuration of the earth's surface, shape and dimension of its landforms (Clarke 1996; Agarwal 1998; Obi Reddy et al. 2002). The morphometric analysis is done successfully through measurement of linear, aerial, relief, gradient of channel network and contributing ground slope of the basin (Nautiyal 1994; Nag and Chakraborty, 2003; Magesh et al. 2012b).

A widely acknowledged principle of morphometry is that drainage basin morphology reflects various geological and geomorphological processes over time, as indicated by various morphometric studies (Horton 1945; Strahler 1952, 1964; Muller 1968; Shreve 1969; Evans 1972, 1984; Chorley et al. 1984; Merritts and Vincent 1989; Ohmori 1993; Cox 1994; Oguchi 1997; Burrough and McDonnell 1998; Hurtrez et al. 1999). It is well established that the influence of drainage morphometry is very significant in understanding the landform processes, soil physical properties and erosional characteristics.

The analysis of the drainage does not appear to be complete if it lacks the systematic approach towards the development of drainage basin in the area. Drainage lines of an area not only explain the existing threedimensional geometry of the region but also help to narrate its evolutional process (Singh 1980). Drainage provides a basic to understand initial gradient, variation in rock resistance, structural control, geological and geomorphologic history of the drainage basin or watershed. Evaluation of morphometric parameters requires 
the analysis of various drainage parameters such as ordering of the various streams, measurement of basin area and perimeter, length of drainage channels, drainage density (Dd), bifurcation ratio $(\mathrm{Rb})$, stream length ratio $(\mathrm{RL})$, and relief ratio (Rh).

Besides, the quantitative analysis of drainage system is an important aspect of characteristic of watershed (Strahler 1964). It is important in any hydrological investigation like assessment of groundwater potential, groundwater management, basin management and environmental assessment.

Hydrologic and geomorphic processes occur within the watershed and morphometric characterization at the watershed scale reveals information regarding formation and development of land surface processes (Singh 1992, 1995; Dar et al. 2013). Drainage characteristics of many river basins and sub-basins in different parts of the globe have been studied using conventional methods (Horton 1945; Strahler 1957, 1964; Krishnamurthy et al. 1996). The surface runoff and flow intensity of the drainage system can be estimated using the geomorphic features associated with morphometric parameters (Ozdemir and Bird 2009). Strahler's system of classification designates a segment with no tributaries as a first-order stream. Where two first-order stream segments join, they form a second-order stream segment and so on. The morphometric analysis of the drainage basin is aimed to acquire accurate data of measurable features of stream network of the drainage basin. Various hydrological phenomena can be correlated with the physiographic characteristics of an drainage basin such as size, shape, slope of the drainage area, drainage density, size and length of the contributories, etc. (Rastogi and Sharma 1976; Magesh et al. 2012a).

The remote sensing technique is the convenient method for morphometric analysis as the satellite images provide a synoptic view of a large area and is very useful in the analysis of drainage basin morphometry. The fast emerging spatial information technology, remote sensing, GIS, and GPS have effective tools to overcome most of the problems of land and water resources planning and management rather than conventional methods of data process (Rao et al. 2010).

GIS-based evaluation using Shuttle Radar Topographic Mission (SRTM) and Advanced Spaceborne Thermal Emission and Reflection Radiometer (ASTER) data has given a precise, fast, and an inexpensive way for analysing hydrological systems (Smith and Sandwell 2003; Grohmann 2004). The processed DEM was used successfully for generating the stream network and other supporting layers (Mesa 2006; Magesh et al. 2011).

The digital elevation model (DEM) of the area was generated to deduce the morphometric parameters like drainage basin area, drainage density, drainage order, relief and network diameter in GIS environment. Combination of the remote sensing satellite data and hydrological and spatial analysis in GIS environment is made easy to identify and discriminate the drainage area (Pirasteh et al. 2010). The geographic and geomorphic characteristics of a drainage basin are important for hydrological investigations involving the assessment of groundwater potential, etc.

The present study aims at using the remote sensing and GIS technology to compute various parameters of morphometric characteristics of the Kanhar River watershed. This is in consonance with the latest developments and researches as cited above.

\section{Study area}

The Kanhar River $\left(23^{\circ} 12^{\prime} \mathrm{N}\right.$ to $24^{\circ} 272^{\prime} \mathrm{N}$ and $83^{\circ} 2^{\prime} \mathrm{E}$ to $84^{\circ} 1^{\prime} \mathrm{E}$ ) is an important tributary of the River Son. The total geographical area of the basin is $5,654 \mathrm{~km}^{2}$. It flows through the Indian states of Chhattisgarh, Jharkhand and Uttar Pradesh (Fig. 1). The Kanhar originates at GidhaDhodha on the Khudia plateau in Jashpur district of Chhattisgarh. It initially flows north forming the boundary with Garhwa district in Palamu division of Jharkhand. Thereafter, it flows for about 100 kilometres (62 miles) through Surguja district of Chhattisgarh.

Subsequently, it runs parallel to the Son River in Garhwa district and turns north-west and flowing through Sonbhadra district in Mirzapur division of Uttar Pradesh. It confluences with the Son River (which itself is the tributary of the national holy river 'Ganges') to the north-east of the village of Kota. Son River plays an important role in increasing the catchment area of Ganga River. It has a rocky bed almost throughout its course. Flowing through forested areas, it becomes a dangerous stream. The elevation of the basin ranges from a low height of $180 \mathrm{~m}$ where the Kanhar meets the Son River to $1,223 \mathrm{~m}$ (Gaurlpat) at Kavradara in Sarguja district of Chhattisgarh.

The tributaries of the Kanhar River are Pangan, Thema, Lauwa, Malia, Pandu, Goitha, Banki, Hathi nala, Suria, Chana, Sendur, Kursa, Galphulla, Semarkhar Rigar, Cherna nala. A number of waterfalls are located along the track of the river. Pavai fall near Kothali village (Balrampur) is of about $61 \mathrm{~m}$. The dense rich forest area provides an abode to thousands of species of flora and fauna. It is the home to various tribes and natives which lived here since long.

The climate of the watershed is characterized by hot summer and well-distributed rainfall during the monsoon season. With its general monsoon character, the region 
according to Thornthwait's classification falls in the Tropical Thermal belt assigns it the grassland type character. According to Trewartha's classification, the Kanhar watershed falls in AW (Tropical Swanah) class which is based on temperature and vegetation. The symbol AW denotes Tropical Swanah region. The chief feature of this climate is long dry period average monthly temperature rising over $18{ }^{\circ} \mathrm{C}$, through maximum summer temperature may even go up to $46{ }^{\circ} \mathrm{C}$. In winter the temperatures does not go below $18{ }^{\circ} \mathrm{C}$. The monsoon brings sufficient rains. The major rainfall recorded at Dudhi ranging 80-90\% occurs mainly in the summer monsoon during June to September, which is very uneven. Maximum rainfall $(293.0 \mathrm{~mm})$ recorded in month of August. The study area is located on the northern fringe of peninsular shield of India. It is very hot during the summers but gets quite cool during the winters. The mean annual temperature in the area is $27.76{ }^{\circ} \mathrm{C}$. The highest value of atmospheric pressure, in the study area, is noted in the month of January $(1,023.2 \mathrm{mb})$ and lowest in the month of June $(1,003.3 \mathrm{mb})$.

\section{Erosion surfaces of the Kanhar basin}

1. Lower Kanhar plain (less than $250 \mathrm{~m}$ ): it is the lowest area being drained by Lauwa, Kanhar, Hathinala and small tributaries of Kanhar River. The denuded hillocks form watersheds for the Kanhar river and its tributaries. The area may be classified as the recent most developed during tertiary orogeny. Limestone, shales and conglomerates are found mixed with sedimentary rocks are met in the area.

2. Middle Kanhar valley $(250-650 \mathrm{~m})$ : It is a long denuded plateau inter spurred with hillocks. The nature and structure of the area are responsible for erosion and recession of rivers.

3. Upper Kanhar plain (650-1,050 m): This area forms the confluence zone of many rivers which join Kanhar from different directions as the upper area and acts as vertical divide between these small rivers where the height of the area is about $1,000 \mathrm{~m}$.

It is a dense forested area also because of the nature of the terrain which restricts transformation from one place to another. This is the most eroded area formed by the river erosion.

4. Highest Kanhar Divide (above 1,050 m): this area lies in the south-western part of Kanhar basin, where a series of flat topped and in pointed hillocks of different size are found. They appeared to have been formed by Archaean rocks. The irregular nature of this surface also indicates the completion of the denudation cycle.
Some of these summits show long continued erosion and which form platforms within the hillocks.

\section{Geomorphological units of Kanhar River basin}

\section{The Upper Kanhar basin}

The Upper Kanhar basin lies in the southern part of basin covering an area of about $1,499.57 \mathrm{~km}^{2}(24.01 \%)$. The notable tributaries of upper Kanhar basin are Semarkhar Nadi, Galphula Nadi and Suria Nadi. In general, the area is hilly with steep slope. The region is characterized by dominance of very high absolute relief, moderate drainage frequency, moderately high relative relief, low dissection index, coarse drainage density and moderate slope. It has been sub divided into four second-order morpho-units, namely Lahsunpat Bhalanad hills, Galphula-Kanhar confluence, Semarkhar-Rigar divide and Kusmi upland.

\section{Middle Kanhar basin}

The middle Kanhar basin lies in the central part of the study basin covering an area of about $3,268.44 \mathrm{~km}^{2}$ or $52.34 \%$. The main tributaries of Kanhar River in this area are Sendur River, Chanan River, Kulwanti River, Rigar River, Sarsotla River, Cherra River, etc. In general, the area is flat and hilly towards western part of middle Kanhar basin and there are waterfalls of up to $30 \mathrm{~m}$. The highest elevation of the basin (1,225 $\mathrm{m}$ Gaurlata) also lies in this region. The region is characterized by dominance of moderate absolute relief and drainage frequency, low relative relief and dissection index, moderately fine drainage density and moderate slope. It has been further divided into $11 \mathrm{~s}$ order morpho-units, namely Thema-Pangan Water Divide, Daukiduba-Pangan Confluence, Jogidah Upland, Kameshwar Nagar UPLAND, Kursa valley, Chutru upland, Biropani valley, Ramanuj Ganj upland, Chumki-Kanhar confluence, Budhudih hills, and Bhandaria upland.

\section{The Lower Kanhar basin}

The lower Kanhar basin lies in the northern part of the basin covering an area of about $1,476.99 \mathrm{~km}^{2}(23.65 \%)$. The tributaries of upper Kanhar watershed are Hathi Nala and Dhanmarwa Nala. In general, the area is plateau type with gentle slope towards North. The region is characterized by dominance of moderately low absolute relief moderate drainage frequency, moderate relative relief, moderate dissection index, coarse drainage density moderate slope.

It has been sub divided into six second-order morphounits, namely Hathwani upland, Kanhar-Malia confluence, Gularia plain, Vinrhamganj upland, Dudhi upland and Baghmandwa upland. 


\section{Methodology}

Manual extraction of drainage network and assigning the stream order from a published Survey of India (SOI) topographic map and from georeferenced satellite data for a large area is a time taking tedious exercise. To overcome this problem, automatic extraction techniques have been used for evaluating the morphometric parameters of a basin, i.e., extraction of River basin/watershed boundary and extraction of drainage/stream network from the Kanhar River basin using ASTER DEM in conjunction with geocoded standard false colour composite remote sensing satellite data (Landsat etm + of 2013) and georeferenced SOI toposheets of 1972 (63P/3, 63P/4, 63P/ 7, 63P/8, 63P/12, 64M/6, 64M/9, 64M/10, 64M/11, 64M/ $12,64 \mathrm{M} / 14,64 \mathrm{M} / 16$ and $73 \mathrm{~A} / 4$ having $1: 50,000$ scale) and Lib Texas Toposheets No-NF44-4, NG44-11, NG44-12, NG44-16 having 1:250,000 scale using ARC GIS-9.3 and ERDAS Imagine-9.1 software's. The extracted basin and stream networks are projected to the regional projection (WGS-1984, UTM zone $44 \mathrm{~N}$ ). The different morphometric parameters have been determined as shown in the Table 1. Landsat etm+ data are used to prepare digital terrain model (DTM) of Kanhar basin for perspective view (Fig. 5c and d) .

\section{Extraction of Kanhar River watershed}

The Kanhar River basin is automatically extracted from the ASTER DEM data with a spatial resolution of $15 \mathrm{~m}$ using the georeferenced SOI toposheets. The contributing basin area was extracted with the help of various geoprocessing techniques in ArcGI-9.3. The DEM and the pour point are the two input parameters required for the extraction purpose. A pour point is a user-supplied point to the cells of highest flow accumulation (Magesh et al. 2013). The pour point of the basin is shown in Fig. 2. The systematic process required for the automatic extraction of the basin/ watershed is shown in Fig. 2. The result of this process will create a watershed boundary polygon from the flow direction raster data.

\section{Extraction of drainage network}

The drainage network of the Kanhar basin is extracted from a series of geoprocessing tools in ARC GIS-9.3 (Fig. 3). The output of this method is a basis for creating a stream/ drainage network grid with stream order based on Strahler 1964. As pointed out above that Strahler's system of classification designates a segment with no tributaries as a first-order stream. Where two first-order stream segments join, they form a second-order stream segment and so on. The highest stream order in the Kanhar basin was identified as seventh. This technique requires two input model parameters: DEM and a minimum upstream area in hectares, which is the minimum drainage area required to create a stream segment (Magesh et al. 2013). The output of the drainage network is smoothened using a smooth line tool in ArcGIS-9.3. To evaluate the drainage basin morphometry, various parameters like stream number, stream order, stream length, stream length ratio, bifurcation ratio, basin length, basin area, relief ratio, elongation ratio, drainage density, stream frequency, form factor and circulatory ratio, etc., have been analysed using the standard mathematical formulae given in Table 1. Moreover, the aspect and slope map of the study area were derived from the ASTER DEM using the aspect and slope tool in ArcGIS-9.3 spatial analyst module (Fig. 4).
Table 1 Linear relief and areal morphometric parameters used for Kanhar river watershed

\begin{tabular}{llll}
\hline S.no. & Parameter & Formula & References \\
\hline 1 & Stream order $(U)$ & Hierarchial rank & Strahler (1964) \\
2 & Stream length $(\mathrm{Lu})$ & Length of the stream & Horton (1945) \\
3 & Mean stream length $(\mathrm{Lsm})$ & $\mathrm{Lsm}=\mathrm{Lu} / \mathrm{Nu}$ & Strahler (1964) \\
4 & Stream length ratio $(\mathrm{RL})$ & $\mathrm{RL}=\mathrm{Lu} / \mathrm{Lu}-1)$ & Horton (1945) \\
5 & Bifurcation ratio $(\mathrm{Rb})$ & $\mathrm{Rb}=\mathrm{Nu} / \mathrm{Nu}+1$ & Schumm (1956) \\
6 & Mean bifurcation ratio $(\mathrm{Rbm})$ & $\mathrm{Rbm}=\mathrm{average}$ of bifurcation & Strahler (1957) \\
& & $\mathrm{ratios}$ of all order & \\
7 & Drainage density (Dd) & $\mathrm{Dd}=\mathrm{Lu} / A$ & Horton (1945) \\
8 & Drainage texture (T) & $T=\mathrm{Dd} \times \mathrm{Fs}$ & Smith (1950) \\
9 & Stream frequency (Fs) & $\mathrm{Fs}=\mathrm{Nu} / A$ & Horton (1945) \\
10 & Elongation ratio (Re) & $\mathrm{Re}=D / L=1.128 \sqrt{ } A / L$ & Schumm (1956) \\
11 & Circulatory ratio & $\mathrm{Rc}=4 \pi A / P^{2}$ & Strahler (1964) \\
12 & Form factor (Ff) & $\mathrm{Ff}=A / L^{2}$ & Horton (1945) \\
13 & Length of overland flow $(\mathrm{Lg})$ & $\mathrm{Lg}=1 / D \times 2$ & Horton (1945) \\
14 & Relief & $R=H-h$ & Hadley and Schumm (1961) \\
15 & Relief ratio & $\mathrm{Rr}=R / L$ & Schumm (1963) \\
\hline
\end{tabular}



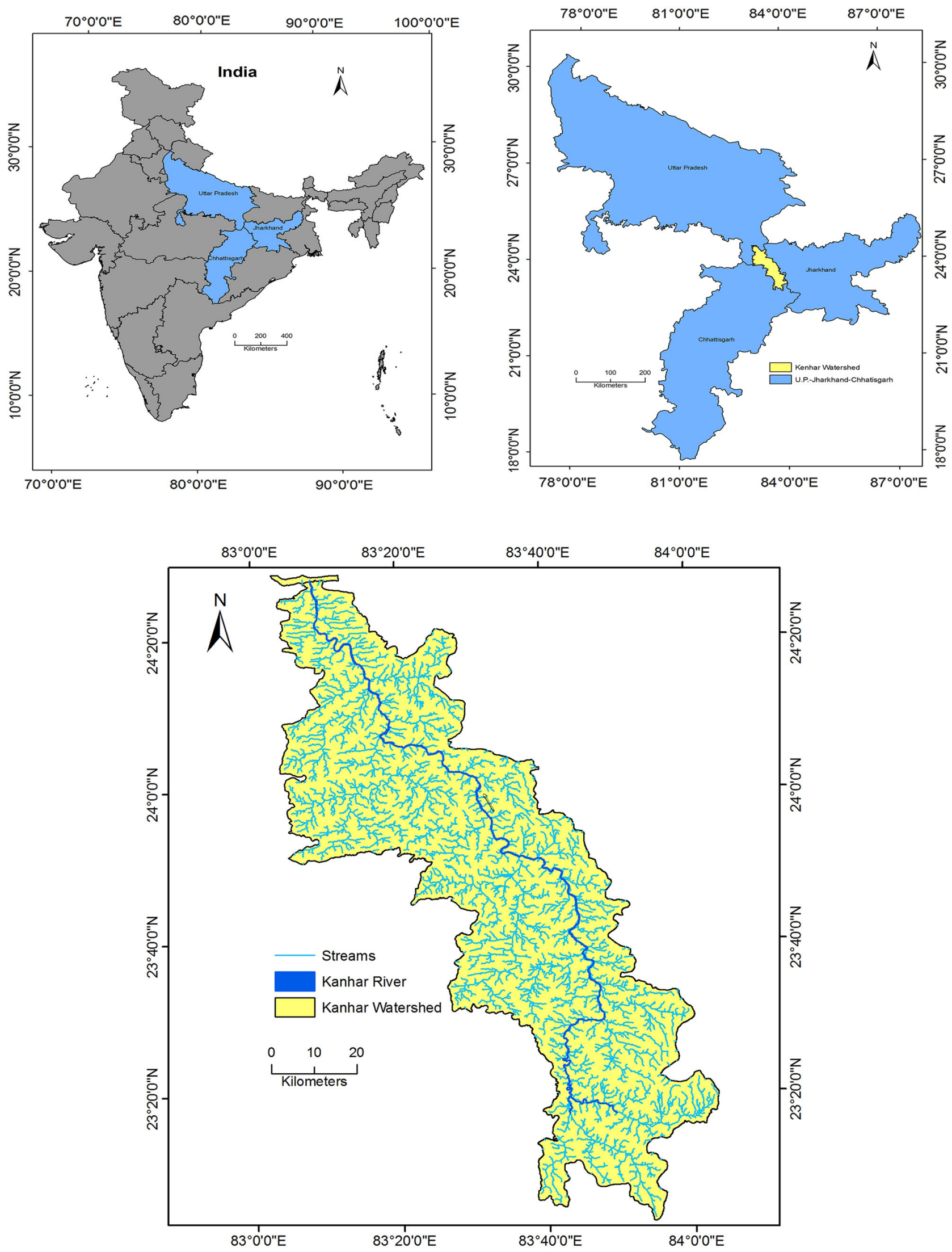

Fig. 1 Location map of the study area 


\section{Watershed Extraction Method From ASTER Data}

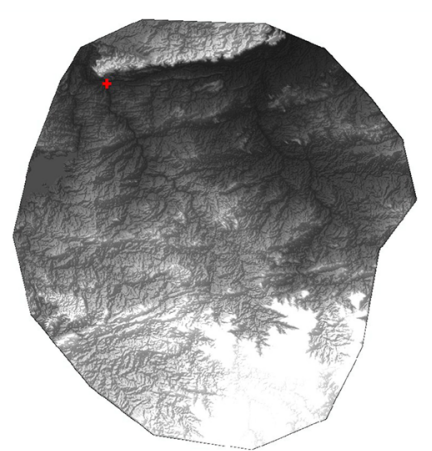

1

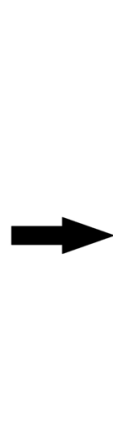

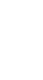

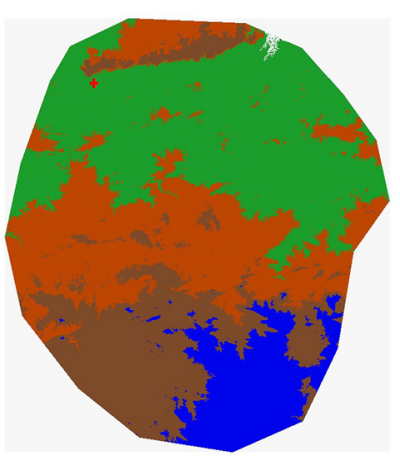

2
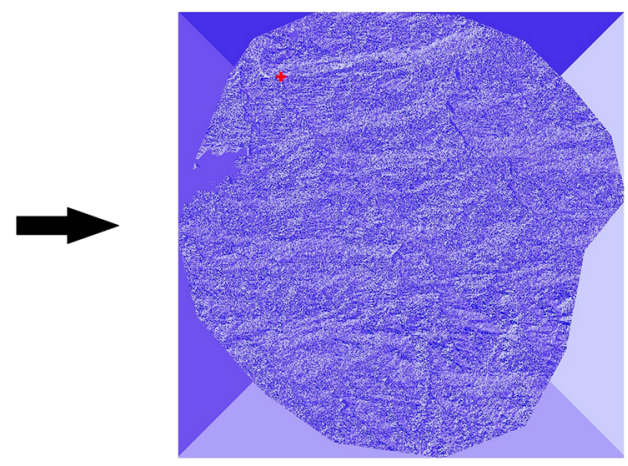

3

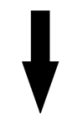

1. Aster DEM

2. Filled ASTER DEM

3. Flow Direction

4. Kanhar Watershed Boundary RASTER

5. Kanhar Watershed Boundary VECTOR

Fig. 2 Extraction of Kanhar River basin boundary through ASTER data

\section{Results and discussion}

The morphometric parameters of Kanhar River basin have been calculated and the results are given in the Table 2 . The total drainage area of the Kanhar River basin is $5,654 \mathrm{~km}^{2}$. The drainage pattern is dendritic in nature and it is influenced by the general topography, geology and rainfall condition of the area. Aster DEM is used to prepare slope, aspect and contour maps. Based on the stream order, the Kanhar basin is classified as seventh-order basin to interpret the morphodynamic parameters as listed in Table 1 (Horton 1932, 1945; Smith 1950; Schumm 1956, 1963; Hadley and Schumm 1961; Strahler 1964; Sreedevi et al. 2005; Mesa 2006). Different sub-watershed of Kanhar River basin is shown in the Fig. 7.

\section{Aspect}

Aspect generally refers to the direction to which a mountain slope faces. The aspect of a slope can make very significant influences on its local climate because the sun's rays are in the west at the hottest time of day in the afternoon, and so in most cases a west-facing slope will be warmer than sheltered east-facing slope. This can have major effects on the distribution of vegetation in the Kanhar watershed area. The value of the output raster data set represents the compass direction of the aspect (Magesh et al. 2011). The aspect map of Kanhar basin is shown in Fig. 6a. It is clearly seen that east-facing slopes mainly occur in the Kanhar basin. Therefore, these slopes have a higher moisture content and lower evaporation rate although and some parts are falling towards west facing which have a lower moisture content and have a high evaporation rate.

\section{Slope}

Slope analysis is an important parameter in geomorphological studies for watershed development and important for morphometric analysis. The slope elements, in turn, are controlled by the climatomorphogenic processes in areas having rock of varying resistance (Magesh et al. 2011; Gayen et al. 2013). A slope map of the study area is calculated based on ASTER DEM data using the spatial 


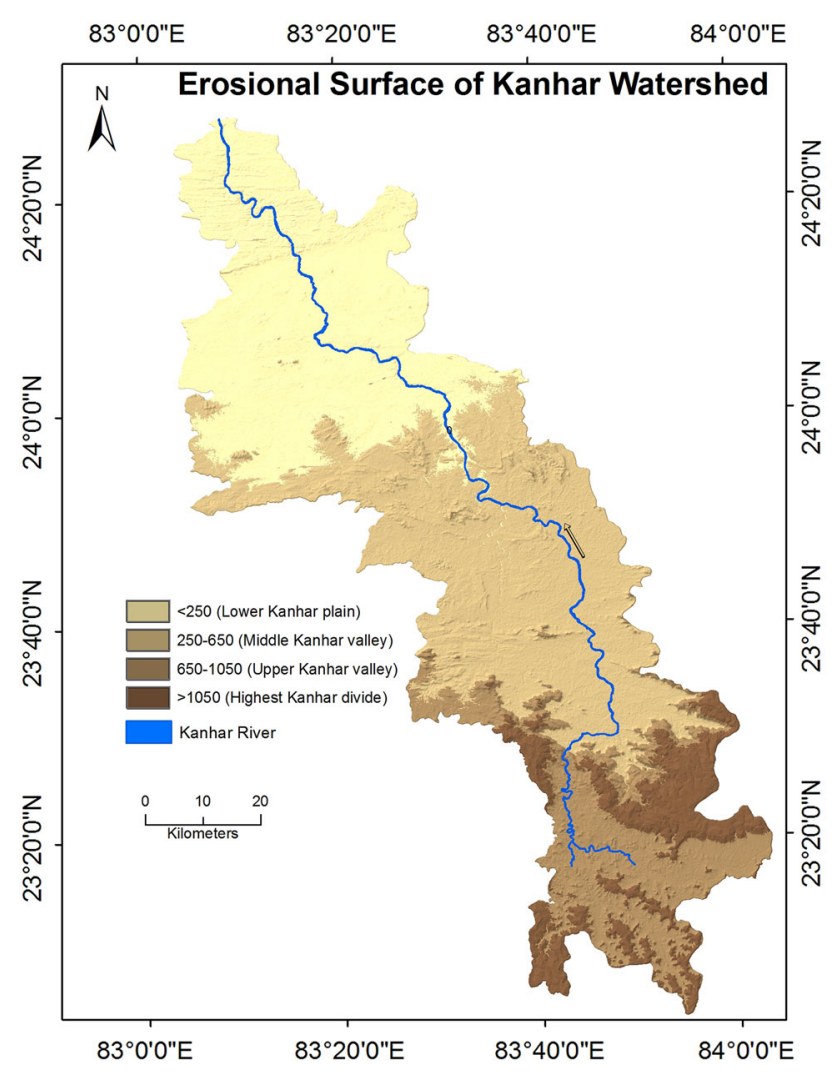

Fig. 3 Erosional surface of Kanhar River basin

analysis tool in ARC GIS-9.3. Slope grid is identified as "the maximum rate of change in value from each cell to its neighbors" (Burrough 1986). The degree of slope in Kanhar watershed varies from $<2.7^{\circ}$ to $>72.37^{\circ}$ (Fig. 6b). The slope map of Kanhar basin is shown in Fig. 5. Higher slope degree results in rapid runoff and increased erosion rate (potential soil loss) with less ground water recharge potential. Higher slope is identified in southern part of the Kanhar basin where it originates.

\section{Relative relief}

Relative relief is an important morphometric variable used for the assessment of morphological characteristics of any topography (Gayen et al. 2013. The highest relative relief is calculated as $1,238 \mathrm{~m}$, while the lowest value is recorded as $151 \mathrm{~m}$ (Fig. 6c). The low relief indicates that the northern area under Kanhar basin is flat to gentle slope type. Therefore, the area could be basically used for agricultural activities around stream sides due to being flat in nature and also a water accessibility.

Stream order (U)

In the present study, ranking of streams has been carried out based on the method proposed by Strahler (1964). The stream orders are classified up to seventh orders in the Kanhar basin. Details of stream order of several tributaries of Kanhar River and their sub-watershed area are shown in the Table 2. Kanhar River could be designated as a seventh-order stream (Fig. 6d; Table 3). The maximum stream order frequency is observed in case of first-order streams and then for second order. Hence, it is noticed that there is a decrease in stream frequency as the stream order increases and vice versa.

Stream number $(\mathrm{Nu})$

The count of stream channels in each order is termed as stream order. As per Horton's law (1945) of stream numbers, "the number of streams of different orders in a given drainage basin tends closely to approximate as inverse geometric series of which the first term is unity and the ratio is the bifurcation ratio".

According to this law, the number of streams counted for each order is plotted on logarithmic scale on the $y$ axis against order on arithmetic scale on the $x$ axis. Number of streams of different orders and the total number of streams in the basin are counted and calculated in GIS platforms. During calculation it is identified that the number of streams gradually decreases as the stream order increases; the variation in stream order and size of tributary basins is largely depends on physiographical, geomorphological and geological condition of the region. 13,987 stream line including Kanhar River is recognized in the whole basin, out of which $68.13 \%(9,541)$ is 1 st order, $23 \%(3,337)$ 2nd order, $6.11 \%$ (856) 3rd order, $1.45 \%$ (204) 4th order, $0.27 \%$ (39) 5th order, $0.064 \%$ (9) 6th order and $0.007 \%$ comprises 7 th order stream (1).

Stream length $(\mathrm{Lu})$

According to Horton (1945), streams lengths delineate the total lengths of stream segment of each of the successive orders in a basin tend to approximate a direct geometric series in which the first term is the average length of the stream of the first order. The stream length is a measure of the hydrological characteristics of the bedrock and the drainage extent. Wherever the bedrock and formation is permeable, only a small number of relatively longer streams are formed in a well-drained watershed, a large number of streams of smaller length are developed where the bedrocks and formations are less permeable (Sethupathi et al. 2011).

The result of order-wise stream length in Kanhar basin is shown in Table 4. It is clearly identified that the cumulative stream length is higher in first-order streams and decreases as the stream order increases. The highest stream order (7th), i.e., for Kanhar River has a length of 

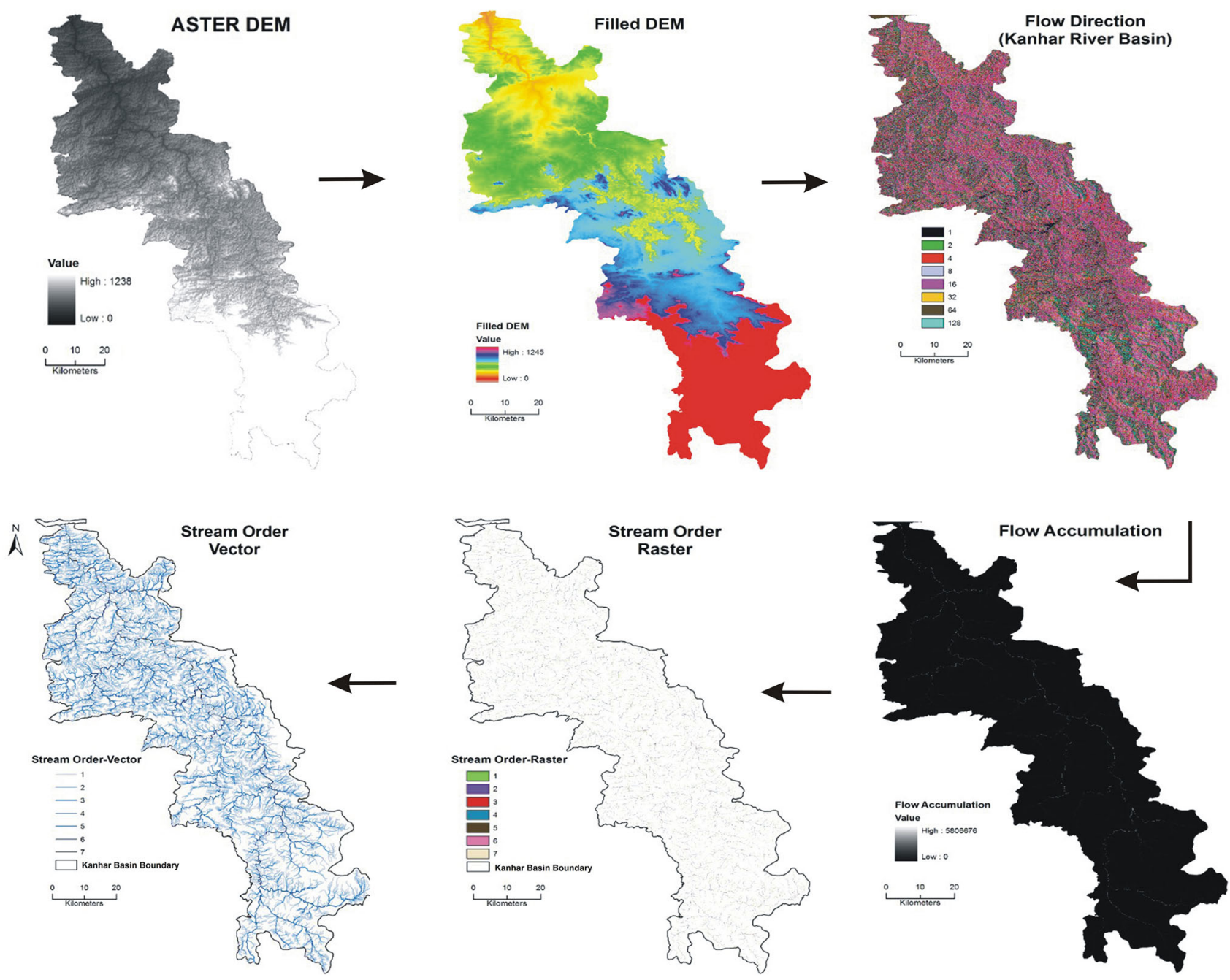

Fig. 4 Automatic extraction of Streams through ASTER data

Table 2 Sub-watershed area of Kanhar basin

\begin{tabular}{llll}
\hline Watershed no. & $\begin{array}{l}\text { Name of the } \\
\text { sub-watershed }\end{array}$ & $\begin{array}{l}\text { Stream } \\
\text { order }\end{array}$ & $\begin{array}{l}\text { Sub-watershed } \\
\text { area }\left(\mathrm{km}^{2}\right)\end{array}$ \\
\hline 1 & Thema Nadi & VI & 215.11 \\
2 & Malia Nala & VI & 217.99 \\
3 & Hathi Nala & V & 44.82 \\
4 & Dhanmarwa Nala & V & 42.38 \\
5 & Suria Nala & V & 117.21 \\
6 & Cherra Nadi & V & 37.89 \\
7 & Sendur Nadi & IV & 457.89 \\
\hline
\end{tabular}

$113.38 \mathrm{~km}$. Stream length of different order under subwatersheds of Kanhar basin is given in Table 4 .

Mean stream length (Lsm)

Mean stream length (Lsm) reveals the characteristic size of components of a drainage network and its contributing surfaces (Strahler 1964). It has been computed by dividing the total stream length of order ' $u$ ' by the number of stream segments in the order (Table 3). The Lsm values for the Kanhar basin range from 0.52 to $113.38 \mathrm{~km}$ (Table 2) with a mean Lsm value of $21.47 \mathrm{~km}$. It is noted that Lsm value of any stream order is greater than that of the lower order and less than that of its next higher order in the basin. The Lsm values differ with respect to different basins, as it is directly proportional to the size and topography of the basin. Strahler (1964) indicated that the Lsm is a characteristic property related to the size of drainage network and its associated surfaces. Mean stream length $(\mathrm{km})$ of subwatershed of Kanhar basin based on stream order is shown in the Table 5 .

Stream length ratio (RL)

Horton's law (1945) of stream length points out that mean stream length segments of each of the successive orders of 

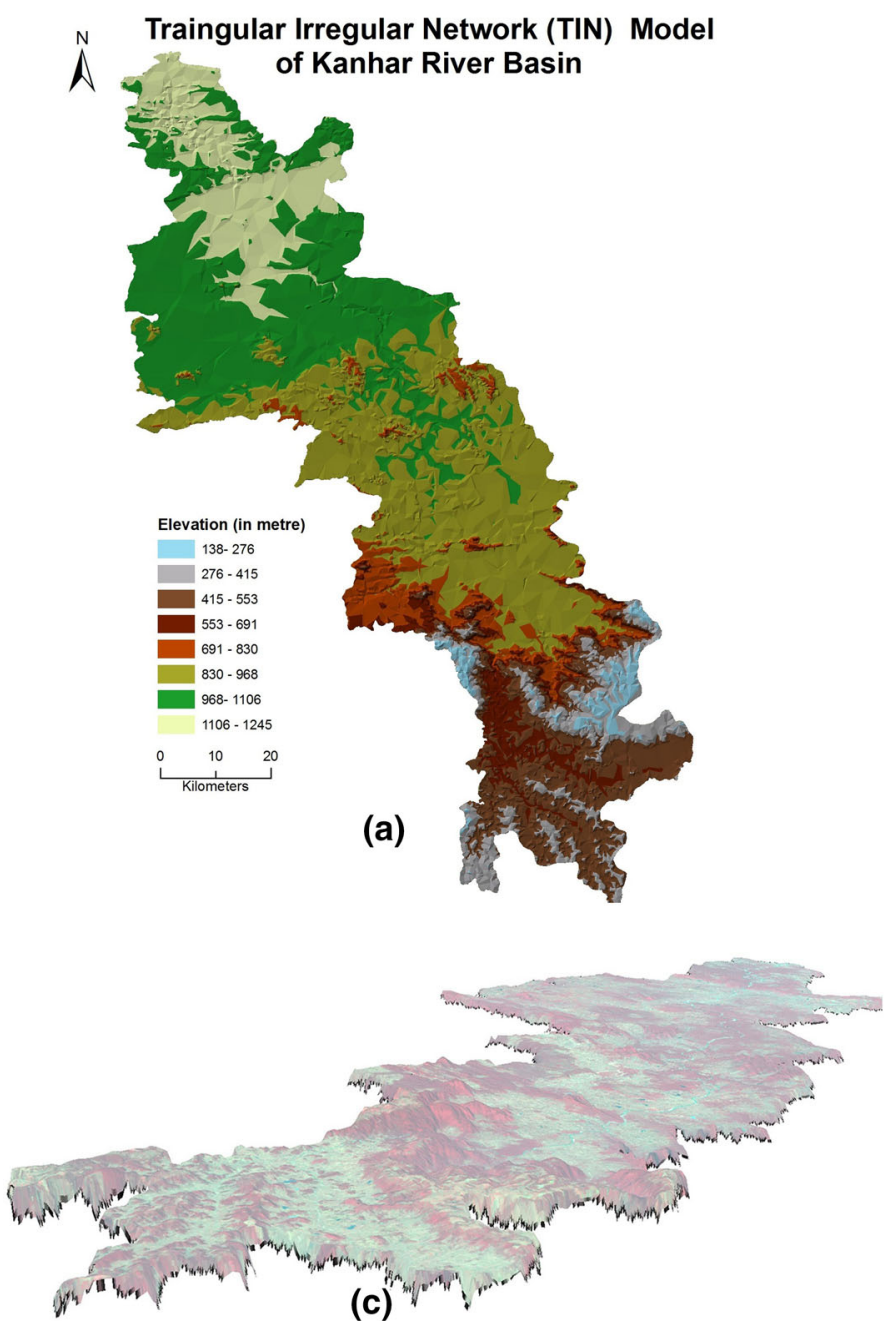
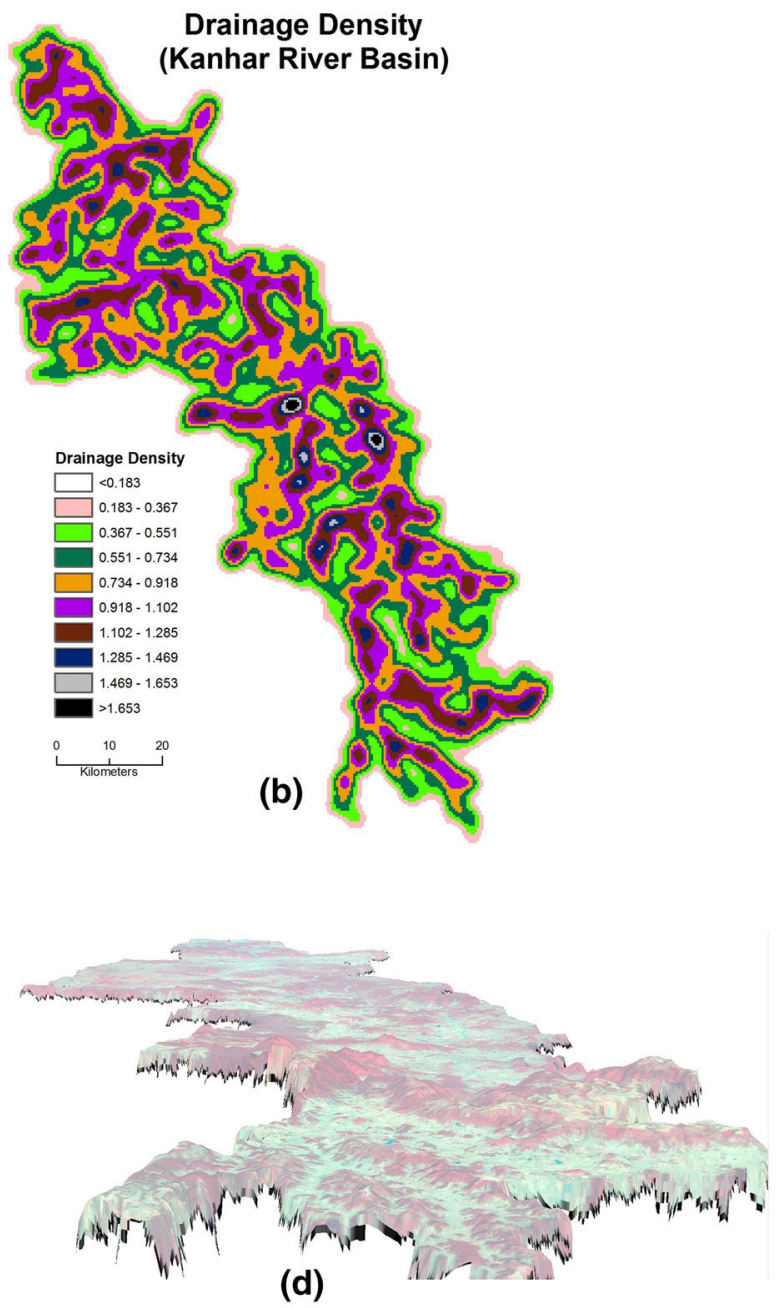

(d)

Fig. 5 Triangular irregular network (a), drainage density map (b) and perspective views of digital terrain model (DTM) from different angles (c, d), respectively

a basin tends to approximate a direct geometric series with stream length increasing towards higher order of streams.

The stream length ratio of Kanhar basin showed an increasing trend. The RL values are presented in Table 2. The stream length ratio between the streams of different orders of the Kanhar basin shows a change in each subwatershed (Table 6). This change might be attributed to variation in slope and topography, indicating the late youth stage of geomorphic development in the streams of the Kanhar basin (Singh and Singh 1997; Vittala et al. 2004).

\section{Bifurcation ratio $(\mathrm{Rb})$}

Horton (1945) considered $\mathrm{Rb}$ as an index of relief and dissection while Strahler (1957) opined that Rb shows only a small variation for different regions with different environments except where powerful geological control dominates. According to Schumn (1956), the term bifurcation ratio $(\mathrm{Rb})$ may be defined as the ratio of the number of the stream segments of given order to the number of segments of the next higher orders. It is a dimensionless property and shows the degree of integration prevailing between streams of various orders in a drainage basin. The $R b$ for the Kanhar basin varies from 2.86 to 9 (Table 2).

According to Strahler (1964), the values of bifurcation ratio characteristically range between 3.0 and 5.0 for drainage basin in which the geological structures do not disturb the drainage pattern. The mean bifurcation ratio ( $\mathrm{Rbm}$ ) characteristically ranges between 3.0 and 5.0 for a basin when the influence of geological structures on the drainage network is negligible (Verstappen 1983). Thus, Verstappen (1983) favours the opinion of Strahler (1964).

In the Kanhar basin, the higher values of $\mathrm{Rb}$ indicate a strong structural control in the drainage pattern whereas the lower values indicate that the sub-basins are less affected by structural disturbances (Strahler 1964; Vittala et al. 2004; Chopra et al. 2005). 

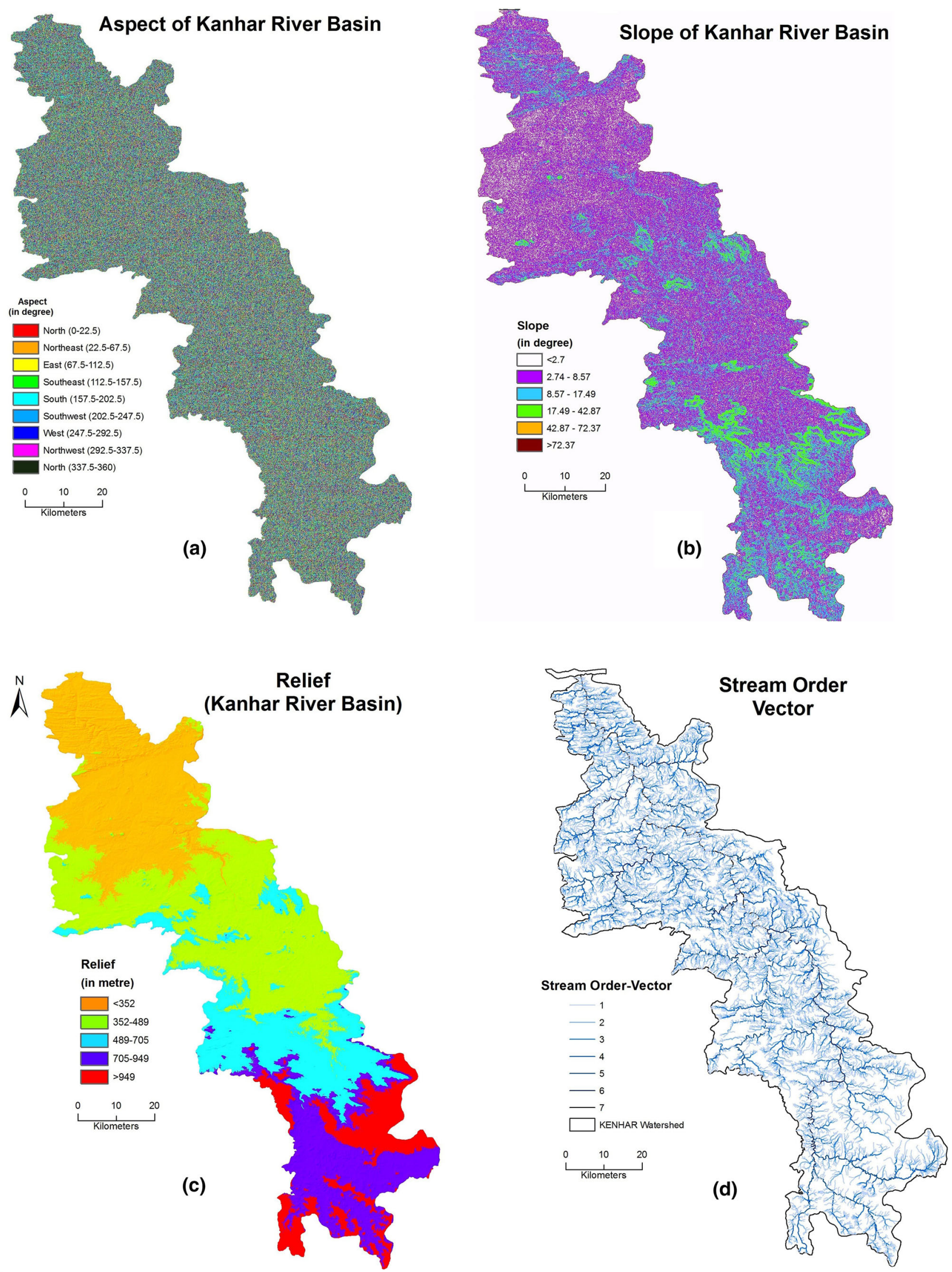

Fig. 6 Aspect map (a), slope map (b), relief map (c) and stream order (d) of Kanhar River basin 
Table 3 Results of morphometric analysis of Kanhar basin

\begin{tabular}{|c|c|c|c|c|c|c|c|c|}
\hline \multirow[t]{2}{*}{ S. no. } & \multirow[t]{2}{*}{ Parameters } & \multicolumn{7}{|c|}{ Stream orders } \\
\hline & & I & II & III & IV & $\mathrm{V}$ & VI & VII \\
\hline 1 & Stream order $(\mathrm{U})$ & 9,541 & 3,337 & 856 & 204 & 39 & 9 & 1 \\
\hline 2 & Stream length (LU) & $4,961.48$ & $2,431.77$ & $1,179.16$ & 594.43 & 306.49 & 212.0 & 113.38 \\
\hline 3 & Mean stream length $(\mathrm{km})(\mathrm{Lsm})$ & 0.52 & 0.73 & 1.37 & 2.91 & 7.86 & 23.56 & 113.38 \\
\hline \multirow[t]{2}{*}{4} & Stream length ratio (RL) & $\mathrm{II} / \mathrm{I}$ & III/II & IV/III & V/IV & $\mathrm{VI} / \mathrm{V}$ & $\mathrm{VII} / \mathrm{VI}$ & \\
\hline & & 0.49 & 0.48 & 0.50 & 0.51 & 0.69 & 0.53 & - \\
\hline \multirow[t]{2}{*}{5} & Bifurcation ratio $(\mathrm{Rb})$ & & $\mathrm{I} / \mathrm{II}$ & II/III & III/IV & $\mathrm{IV} / \mathrm{V}$ & $\mathrm{V} / \mathrm{VI}$ & $\mathrm{VI} / \mathrm{VII}$ \\
\hline & & & 2.86 & 3.89 & 4.19 & 5.23 & 4.33 & 9 \\
\hline 6 & Mean bifurcation ratio (Rbm) & 4.92 & & & & & & \\
\hline 7 & Perimeter $(\mathrm{P})$ (in km) & 694.93 & & & & & & \\
\hline 8 & Basin length (Lb) (km) & 174.964 & & & & & & \\
\hline 9 & Basin area $(\mathrm{km})$ & $5,703.75$ & & & & & & \\
\hline 10 & Total relief $(\mathrm{R})(\mathrm{m})$ & 900 & & & & & & \\
\hline 11 & Relief ratio $(\mathrm{Rh})$ & 0.092 & & & & & & \\
\hline 12 & Elongation ratio $(\mathrm{Re})$ & 0.48 & & & & & & \\
\hline 13 & Length of over land flow (Lg) & 0.58 & & & & & & \\
\hline 14 & Drainage density (D) $\left(\mathrm{km} / \mathrm{km}^{2}\right)$ & 1.72 & & & & & & \\
\hline 15 & Stream frequency $(\mathrm{Fs})$ & 2.45 & & & & & & \\
\hline 16 & Texture ratio $(\mathrm{Rt})$ & 4.24 & & & & & & \\
\hline 17 & Form factor (Rf) & 0.18 & & & & & & \\
\hline 18 & Circulatory ratio (Rc) & 0.15 & & & & & & \\
\hline
\end{tabular}

Table 4 Stream length of different sub-watershed of Kanhar basin

\begin{tabular}{lllllllll}
\hline \multirow{2}{*}{$\begin{array}{l}\text { Watershed } \\
\text { number }\end{array}$} & $\begin{array}{l}\text { Name of the } \\
\text { sub-watershed }\end{array}$ & \multicolumn{7}{l}{ Stream length $(\mathrm{km})$} \\
\cline { 3 - 9 } & & I & II & III & IV & V & VI \\
\hline 1 & Thema Nadi & 242 & 105 & 52.7 & 20.3 & 9.5 & 24.3 \\
2 & Malia Nala & 244 & 123 & 69.4 & 28 & 11.6 & 13 \\
3 & Hathi Nala & 49.5 & 29 & 14.3 & 22 & 2 & - & \\
4 & Dhanmarwa Nala & 65.4 & 27 & 18.4 & 5.3 & 2.1 & - \\
5 & Suria Nala & 61.2 & 33 & 10.5 & 17 & 16 & - \\
6 & Cherra Nadi & 40 & 12.6 & 10 & 1.6 & - & - \\
7 & Sendur Nadi & 389 & 193 & 93.2 & 43.8 & 45 & 5.7 \\
\hline
\end{tabular}

Table 5 Mean stream length $(\mathrm{km})$ of sub-watershed of Kanhar basin based on stream order

\begin{tabular}{lllllll}
\hline Sub-watershed & \multicolumn{7}{l}{ Mean stream length $(\mathrm{km})$} \\
\cline { 2 - 7 } & I & II & III & IV & V & VI \\
\hline Thema Nadi & 0.54 & 0.57 & 1.41 & 1.63 & & \\
Malia Nala & 0.48 & 0.68 & 1.38 & 3.12 & 3.86 & 2.18 \\
Hathi Nala & 0.36 & 0.65 & 1.43 & 4.40 & 1.97 & \\
Dhanmarwa Nala & 0.46 & 0.574 & 1.53 & 2.65 & 2.19 & \\
Suria Nala & 0.52 & 0.870 & 1.49 & 8.50 & 16.90 & \\
Cherra Nadi & 0.54 & 0.57 & 1.41 & 1.63 & & \\
Sendur Nadi & 0.51 & 0.749 & 1.45 & 3.13 & 22.39 & 5.75 \\
\hline
\end{tabular}

Table 6 Stream length ratio of sub-watershed of Kanhar basin

\begin{tabular}{|c|c|c|c|c|c|c|}
\hline \multirow{2}{*}{$\begin{array}{l}\text { Sub- } \\
\text { watershed } \\
\text { no. }\end{array}$} & \multirow[t]{2}{*}{ Sub-watershed } & \multicolumn{5}{|c|}{ Stream length ratio } \\
\hline & & I-II & II-III & III-IV & IV-V & $\mathrm{V}-\mathrm{VI}$ \\
\hline 1 & Thema Nadi & 1.434 & 0.151 & 0.386 & 0.25 & 1.5 \\
\hline 2 & Malia Nala & 0.503 & 0.565 & 0.404 & 0.412 & 1.131 \\
\hline 3 & Hathi Nala & 0.584 & 0.494 & 1.537 & - & - \\
\hline 4 & Dhanmarwa Nala & 0.413 & 0.681 & 0.288 & 0.413 & - \\
\hline 5 & Suria Nala & 0.539 & 0.316 & 1.625 & 0.993 & - \\
\hline 6 & Cherra Nadi & 0.342 & 0.783 & 0.164 & - & - \\
\hline 7 & Sendur Nadi & 0.494 & 0.484 & 0.470 & 1.021 & 0.128 \\
\hline
\end{tabular}

The mean bifurcation ratio ( $\mathrm{Rbm})$ may be defined as the average of bifurcation ratios of all order (Table 2) and it is 4.92 in case of Kanhar River basin. In the present study, Rb for the each sub-watershed of Kanhar basin is given in the Table 7 .

\section{Relief ratio $(\mathrm{Rh})$}

Schumm (1956) states that the maximum relief to horizontal distance along the longest dimension of the basin parallel to the principal drainage line is termed as relief ratio. Difference in the elevation between the highest point of a basin and the lowest point on the valley floor is termed 
Table 7 Bifurcation ratio of sub-watershed of Kanhar basin

\begin{tabular}{|c|c|c|c|c|c|c|}
\hline \multirow{2}{*}{$\begin{array}{l}\text { Sub- } \\
\text { watershed } \\
\text { no. }\end{array}$} & \multirow[t]{2}{*}{ Sub-watershed } & \multicolumn{5}{|c|}{ Bifurcation ratio } \\
\hline & & I-II & II-III & III-IV & IV-V & $\mathrm{V}-\mathrm{Y}$ \\
\hline 1 & Thema Nadi & 2.608 & 4.105 & 4.75 & 4.0 & 0.666 \\
\hline 2 & Malia Nala & 2.853 & 3.56 & 5.55 & 3.0 & 3.0 \\
\hline 3 & Hathi Nala & 3.090 & 4.40 & 2.0 & 5.0 & - \\
\hline 4 & Dhanmarwa Nala & 3.0 & 3.916 & 6.0 & 2.0 & - \\
\hline 5 & Suria Nala & 3.052 & 5.428 & 3.5 & 2.0 & - \\
\hline 6 & Cherra Nadi & 3.090 & 3.142 & 7.0 & - & - \\
\hline 7 & Sendur Nadi & 0.341 & 0.249 & 0.218 & 0.142 & 0.5 \\
\hline
\end{tabular}

Table 8 Relief Ratio of sub-watershed of Kanhar basin

\begin{tabular}{lllll}
\hline $\begin{array}{l}\text { Sub-watershed } \\
\text { no. }\end{array}$ & Sub-watershed & $\begin{array}{l}\text { Total } \\
\text { relief }(\mathrm{m})\end{array}$ & $\begin{array}{l}\text { Maximum } \\
\text { length }(\mathrm{km})\end{array}$ & $\begin{array}{l}\text { Relief } \\
\text { ratio }\end{array}$ \\
\hline 1 & Thema Nadi & 180 & 696.198 & 0.258 \\
2 & Malia Nala & 125 & 217.998 & 0.573 \\
3 & Hathi Nala & 100 & 67.286 & 1.486 \\
4 & Dhanmarwa Nala & 120 & 118.162 & 1.015 \\
5 & Suria Nala & 275 & 138.682 & 1.982 \\
6 & Cherra Nadi & 100 & 61.132 & 2.944 \\
7 & Sendur Nadi & 260 & 676.282 & 0.384 \\
\hline
\end{tabular}

as the total relief of that river basin. Schumm (1963) also stated that it is a dimensionless height-length ratio equal to the tangent of angle formed by two planes intersecting at the mouth of the basin, one representing the horizontal and other passing through the highest point of the basin.

Low value of relief ratios is mainly due to the resistant basement rocks of the basin and low degree of slope (Mahadevaswamy et al. 2011). The Rh normally increases with decreasing drainage area and size of a given drainage basin (Gottschalk 1964). Rh for Kanhar basin is calculated, i.e., 0.092. Mean relief ratio of each sub-watershed of Kanhar basin is shown in the Table 8 .

\section{Elongation ratio $(\mathrm{Re})$}

Elongation ratio $(\mathrm{Re})$ is defined as the ratio of diameter of a circle having the same area as of the basin and maximum basin length (Schumm 1956). It is a measure of the shape of the river basin and it depends on the climatic and geologic types. A circular basin is more efficient in runoff discharge than an elongated basin (Singh and Singh 1997). Re value of Kanhar basin is 0.48. Higher values of elongation ratio show high infiltration capacity and low runoff, whereas lower Re values which are characterized by high susceptibility to erosion and sediment load (Reddy et al. 2004).
Table 9 Drainage density of sub-watersheds of Kanhar basin

\begin{tabular}{lccl}
\hline Sub-watershed & $\begin{array}{l}\text { Stream } \\
\text { length }(\mathrm{km})\end{array}$ & $\begin{array}{l}\text { Area } \\
(\mathrm{km})\end{array}$ & $\begin{array}{l}\text { Drainage } \\
\text { density }\end{array}$ \\
\hline Cherra River & 61.13 & 37.89 & 1.61 \\
Dhanmarawa River & 118.16 & 42.00 & 2.81 \\
Hathi Nala River & 67.28 & 44.82 & 1.50 \\
Suria River & 138.68 & 117.21 & 1.18 \\
Thema River & 696.19 & 215.00 & 3.23 \\
Malia River & 477.35 & 217.99 & 2.18 \\
Sendur River & 676.28 & 457.89 & 1.47 \\
\hline
\end{tabular}

Drainage density (Dd)

Drainage density (Dd) is a measure the total stream length in a given basin to the total area of the basin (Strahler 1964).The drainage density is affected by the factors that control characteristic length of the watershed. Drainage density is related to various features of landscape dissection such as valley density, channel head source area, relief, climate and vegetation (Moglen et al. 1998), soil and rock properties (Kelson and Wells 1989) and landscape evolution processes. The drainage density of the Kanhar basin is $1.72 \mathrm{~km} / \mathrm{km}^{2}$, which indicates that basin area has a highly resistant permeable subsurface material with intermediate drainage and low to moderate relief. Higher drainage density is associated with the basin of weak and impermeable subsurface material, sparse vegetation and high relief. Low drainage density leads to coarse drainage texture while high drainage density leads to fine drainage texture, high runoff and erosion potential of the basin area. (Strahler 1964). Drainage density of each sub-watershed of Kanhar basin is given in the Table 9. Higher density (3.23) is identified for Thema River sub-watershed whereas low drainage density (1.18) is calculated for Suria River subwatershed (Table 9). Triangular irregular network (a), drainage density (b) and DTM from different angles for perspective views are shown in the Fig. 5.

Stream frequency $(\mathrm{Sf})$

Stream frequency (Sf) is the total number of stream segments of all orders per unit area (Horton 1932). Reddy et al. (2004)) stated that low values of stream frequency Sf indicate presence of a permeable subsurface material and low relief. The channel segment numbers for unit areas are difficult to be enumerated (Singh 1980), but an attempt has been made to count stream frequency of Kanhar basin. The stream frequency value of the Kanhar basin is $2.45 \mathrm{~km} /$ $\mathrm{km}^{2}$. Stream frequency mainly depends on the lithology of the basin and reflects the texture of the drainage network. The value of stream frequency (Fs) for the basin exhibits 
positive correlation with the drainage density value of the area indicating the increase in stream population with respect to increase in drainage density.

Channel frequency density serves as a tool in establishing the erosional processes operating over an area; to be more specific, the same in relation to the stream orders and their characteristics provides data which can throw light even on the sequences of relief developments and the degree of ruggedness in the area (Singh 1980).

\section{Form factor (Rf)}

Horton (1932) stated form factor as the ratio of the area of the basin and square of the basin length. The value of form factor would always be greater than 0.78 for perfectly circular basin. Smaller the value of form factor, more elongated will be the basin. Rf value of the Kanhar basin is 0.18 (Table 2). Thus, the Kanhar basin is elongated one.

\section{Circularity ratio $(\mathrm{Rc})$}

Miller (1953) stated circularity ratio is the ratio of the area of the basins to the area of circle having the same circumference as the perimeter of the basin. Miller (1953) described Rc as a significant ratio that indicates the dendritic stage of a watershed. This is mainly due to the diversity of slope and relief pattern of the basin. The circulator ratio is mainly concerned with the length and frequency of streams, geological structures, land use/land cover, climate, relief and slope of the basin. It is a significant ratio that indicates the dendritic stage of a watershed. Low, medium and high values of Rc indicate the young, mature, and old stages of the life cycle of the tributary watershed (John Wilson et al. 2012). Rc value of Kanhar basin is 0.15 (Table 2). In the study area, Rc value of different sub-watershed of Kanhar basin is ranging from 0.246 to 0.411 (Table 10; Fig. 7).

Table 10 Circulatory ratio of sub-watersheds of Kanhar basin

\begin{tabular}{llrl}
\hline $\begin{array}{l}\text { Sub- } \\
\text { watershed no. }\end{array}$ & Sub-watershed & $\begin{array}{l}\text { Perimeter } \\
(\mathrm{km})\end{array}$ & $\begin{array}{l}\text { Circularity } \\
\text { ratio }\end{array}$ \\
\hline 1 & Thema Nadi & 81.00 & 0.411 \\
2 & Malia Nala & 217.99 & 0.351 \\
3 & Hathi Nala & 39.40 & 0.362 \\
4 & Dhanmarwa Nala & $2,913.00$ & 0.627 \\
5 & Suria Nala & 59.05 & 0.422 \\
6 & Cherra Nadi & 29.86 & 0.042 \\
7 & Sendur Nadi & 152.64 & 0.246 \\
\hline
\end{tabular}

\section{Conclusion}

Morphometric analysis of drainage system is prerequisite to any hydrological study. Thus, determination of stream networks' behaviour and their interrelation with each other is of great importance in many water resources studies. Remote sensing satellite data and GIS techniques have been proved to be an effective tool in drainage delineation. Their updation in conjunction with old datasets brings a bright picture enabling geomorphologist to infer concrete conclusion about the drainage basin. In the present paper, morphometric analysis of the Kanhar River basin, based on several drainage parameters using remote sensing satellite data and latest GIS tools for drainage analysis, has been delineated. It is inferred that the Kanhar River falls under seventh-order basin. Kanhar basin is mainly dominated by lower order streams. The morphometric analysis is carried by the measurement of linear, aerial and relief aspects of basins. Detailed morphometric study of all sub-watersheds shows dendritic to sub-dendritic drainage patterns, which thus indicate homogenous lithology and variations of values of $\mathrm{Rb}$ among the sub-watersheds attributed to difference in topography and geometric development. The maximum stream order frequency is observed in case of first-order streams and then for second order. Hence, it is noticed that there is a decrease in stream frequency as the stream order increases and vice versa. The values of stream frequency indicate that all the sub-basins show + ve correlation with increasing stream population with respect to increasing drainage density.

The drainage density values of the Kanhar basin have values below five revealing that the subsurface area is permeable, a characteristic feature of coarse drainage. The variation of stream length ratio might be due to differences in slope/gradients and topographic conditions of the area. The values of stream frequency indicate that all the subwatershed show positive correlation with increasing stream segments with respect to increasing drainage density. Elongation ratio $(\mathrm{Re})$ value of Kanhar basin is 0.48 . Higher values of elongation ratio show high infiltration capacity and low runoff, whereas lower Re values which are characterized by high susceptibility to erosion and sediment load The database obtains through analysis of morphometric parameters would be suggested for its proper utilization in the integrated watershed programme aimed at development and management of water resources of the Kanhar River basin by the ministry of water resources, New Delhi (India) in future.

The used approaches in this study include a comprehensive morphometric analysis that can be applied for any drainage system elsewhere. They introduce the major elements needed to assess water resources and their

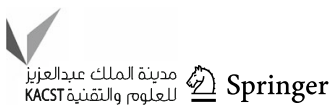




\section{Sub-Watersheds of Kanhar Basin}
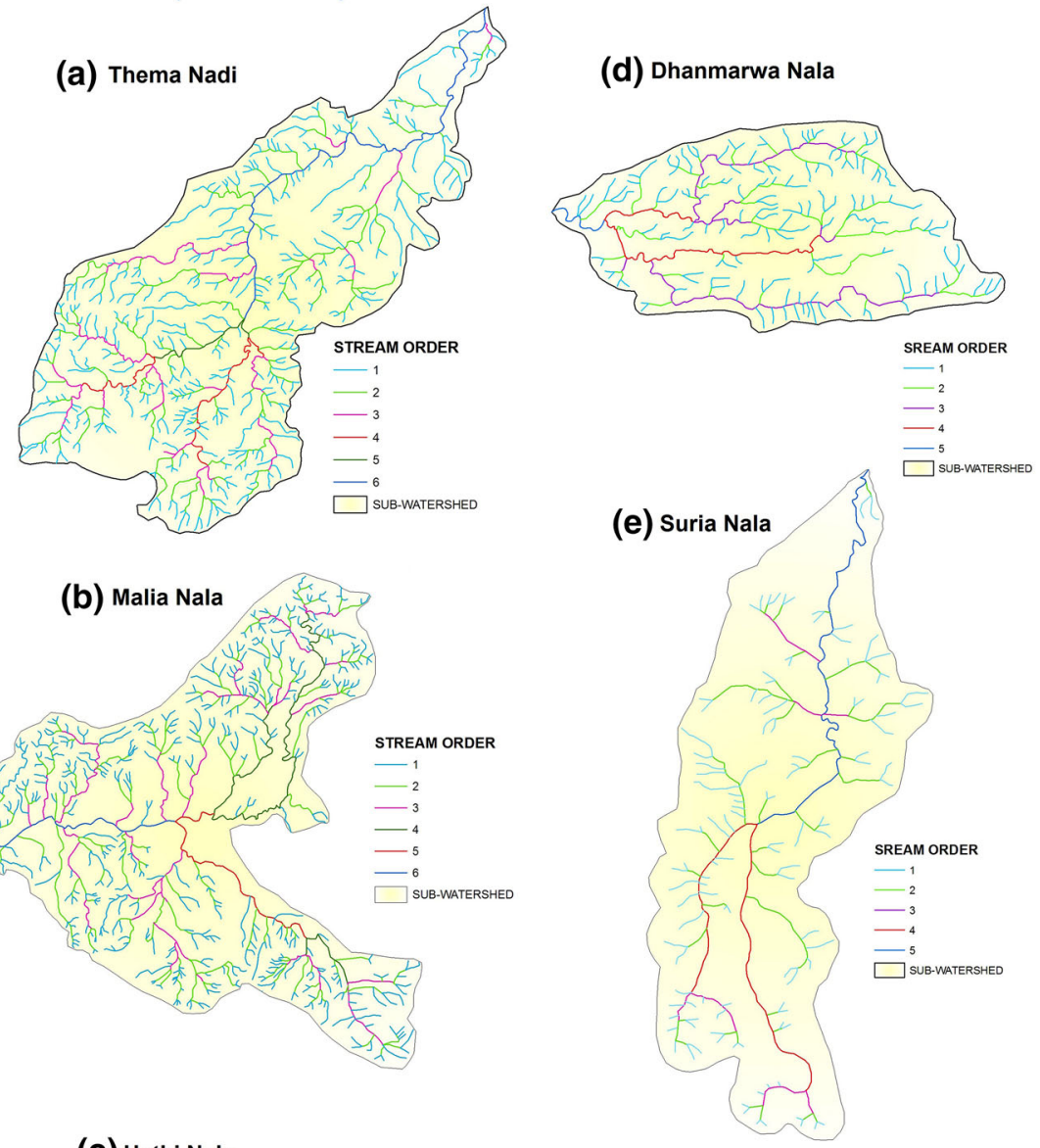

(c) Hathi Nala

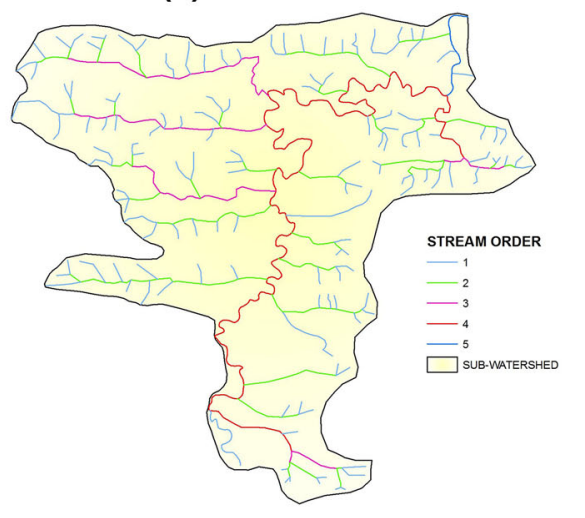

(f) Cherra Nadi
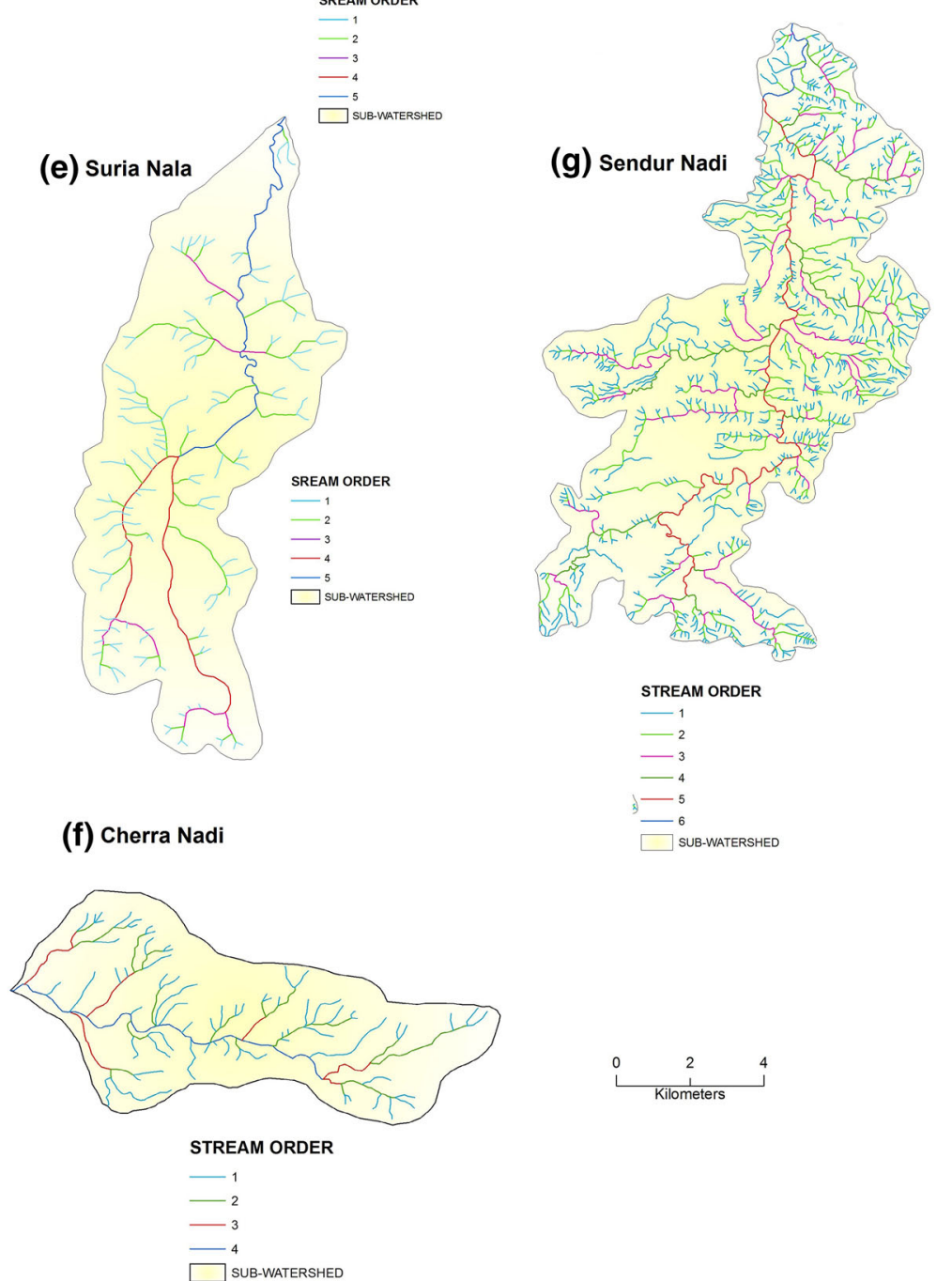

Fig. 7 Sub-watershed of Kanhar River basin (a-g)

hydrologic regime, thus it is recommended to apply similar studies in anywhere in India.

The general budget, 2014-2015 passed in the Lok Sabha on 10th of July 2014 also promises for proper management of different water resources of the country. The result calculated in this paper will suggest and recommend developing a better water usage mechanism for proper watershed management in the Kanhar River basin.
Open Access This article is distributed under the terms of the Creative Commons Attribution License which permits any use, distribution, and reproduction in any medium, provided the original author(s) and the source are credited.

\section{References}

Agarwal CS (1998) Study of drainage pattern through aerial data in Naugarh area of Varanasi district, U.P. J Indian Soc Remote Sens 26:169-175 
Burrough PA (1986) Principles of geographical information systems for land resources assessment. Oxford University Press, New York, p 50

Burrough PA, McDonnell RA (1998) Principles of geographical information systems. Oxford University Press Inc., New York

Chopra R, Raman DD, Sharma PK (2005) Morphometric analysis of sub-watersheds in Gurdaspur district, Punjab using remote sensing and GIS techniques. J Indian Soc Remote Sens 33(4):531-539

Chorley RJ, Schumm SA, Sugden DE (1984) Geomorphology. Methuen, London

Clarke JI (1996) Morphometry from Maps. Essays in geomorphology. Elsevier publication. Co., New York, pp 235-274

Cox RT (1994) Analysis of drainage-basin symmetry as a rapid technique to identify areas of possible quaternary tilt-block tectonics: an example from the Mississippi embayment. Geol Soc Am Bull 106:571-581

Dar RA, Chandra R, Romshoo SA (2013) Morphotectonic and lithostratigraphic analysis of intermontane Karewa basin of Kashmir Himalayas, India. J Mt Sci 10(1):731-741

Evans IS (1972) General geomorphometry, derivatives of altitude, and descriptive statistics. In: Chorley RJ (ed) Spatial analysis in geomorphology. Harper and Row, New York, pp 17-90

Evans IS (1984) Correlation structures and factor analysis in the investigation of data dimensionality: statistical properties of the Wessex land surface, England. In: Proceedings of the Int. Symposium on Spatial Data Handling, Zurich., v 1. Geographisches Institut, Universitat Zurich-Irchel. pp 98-116

Gayen S, Bhunia GS, Shi PK (2013) Morphometric analysis of Kangshabati-Darkeswar Interfluves area in West Bengal, India using ASTER DEM and GIS techniques. Geol Geosci 2(4):1-10

Gottschalk LC (1964) Reservoir sedimentation in handbook of applied hydrology. McGraw Hill Book Company, New York (Section 7-1)

Grohmann CH (2004) Morphometric analysis in geographic information systems: applications of free software GRASS and R. Comput Geosci 30:1055-1067

Hadley RF, Schumm SA (1961) Sediment sources and drainage basin characteristics in upper Cheyenne River Basin. US Geol Survey Water Supply Paper 1531-B:198

Horton RE (1932) Drainage basin characteristics. Am Geophys Union Trans 13:348-352

Horton RE (1945) Erosional development of streams and their drainage basins; hydrophysical approach to quantitative morphology. Bull Geol Soc Am 56:275-370

Hurtrez JE, Sol C, Lucazeau F (1999) Effect of drainage area on hypsometry from an analysis of small-scale drainage basins in the Siwalik hills (central Nepal). Earth Surf Process Landform 24:799-808

John Wilson JS, Chandrasekar N, Magesh NS (2012) Morphometric analysis of major Sub Watersheds in Aiyar \& Karai Pottanar Basin, Central Tamil Nadu, India using Remote Sensing \& GIS Techniques. Bonfring Int J Ind Eng Manag Sci 2(special issue 1):8-15

Kelson KI, Wells SG (1989) Geologic influences on fluvial hydrology and bedload transport in small mountainous watersheds, northern New Mexico, USA. Earth Surf Process 14:671-690

Krishnamurthy J, Srinivas G, Jayaram V, Chandrasekhar MG (1996) Influence of rock type and structure in the development of drainage networks in typical hard rock terrain. ITC J 4(3):252-259

Magesh NS, Chandrasekar N, Soundranayagam JP (2011) Morphometric evaluation of Papanasam and Manimuthar watersheds, parts of Western Ghats, Tirunelveli district, Tamil Nadu, India: a GIS approach. Environ Earth Sci 64(2):373-381

Magesh NS, Chandrasekar N, Kaliraj S (2012a) A GIS based automated extraction tool for the analysis of basin morphometry. Bonfring Int J Ind Eng Manag Sci 2(1):32-35
Magesh NS, Jitheshlal KV, Chandrasekar N, Jini KV (2012b) GIS based morphometric evaluation of Chimmini and Mupily watersheds, parts of Western Ghats, Thrissur District, Kerala. India Earth Sci Inform 5(2):111-121

Magesh NS, Jitheshal KV, Chandrasekar N. Jini KV (2013) Geographical information system based morphometric analysis of Bharathapuzha River Basin, Kerla, India. Appl Water Sci:1-11. doi:10.1007/s13201-013-0095-0

Mahadevaswamy G, Nagaraju D, Siddalingamurthy S, Lakshmamma MSL, Nagesh PC, Rao K (2011) Morphometric analysis of Nanjangud taluk, Mysore District, Karnataka, India, using GIS Techniques. Int J Geomat Geosci 1:179-187

Merritts D, Vincent KR (1989) Geomorphic response of coastal streams to low, intermediate, and high rates of uplift, Mendocino junction region, northern California. Geol Soc Am Bull 101:1373-1388

Mesa LM (2006) Morphometric analysis of a subtropical Andean basin (Tucuman, Argentina). J Environ Geol 50(8):1235-1242

Miller VC (1953) A quantitative geomorphologic study of drainage basin characteristics in the Clinch Mountain area, Virginia and Tennessee, Project NR 389042, Tech Report 3. Columbia University Department of Geology, ONR Geography Branch, New York

Moglen GE, Eltahir EA, Bras RL (1998) On the sensitivity of drainage density to climate change. Water Resour Res 34:855-862

Muller JE (1968) An introduction to the hydraulic and topographic sinuosity indexes. Ann Assoc Am Geogr 58:371-385

Nag SK, Chakraborty S (2003) Influence of rock types and structures in the development of drainage network in hard rock area. J Indian Soc Remote Sens 31(1):25-35

Nautiyal MD (1994) Morphometric analysis of a drainage basin, district Dehradun, Uttar Pradesh. J Indian Soc Remote Sens 22(4):251-261

Obi Reddy GE, Maji AK, Gajbhiye KS (2002) GIS for morphometric analysis of drainage basins. GIS lndia 4(11):9-14

Oguchi T (1997) Drainage density and relative relief in humid steep mountains with frequent slope failure. Earth Surf Process Landf 22:107-120

Ohmori H (1993) Changes in the hypsometric curve through mountain building resulting from concurrent tectonics and denudation. Geomorphology 8:263-277

Ozdemir H, Bird D (2009) Evaluation of morphometric parameters of drainage networks derived from topographic maps and DEM in point floods. Environ Geol 56:1405-1415

Pirasteh S, Safari HO, Pradhan B, Attarzadeh I (2010) Litho morphotectonics analysis using Landsat ETM data and GIS techniques: Zagros Fold Belt (ZFB), SW Iran

Rao NK, Swarna LP, Kumar AP, Krishna HM (2010) Morphometric analysis of Gostani River Basin in Andhra Pradesh State, Indian using spatial information technology. Int $\mathrm{J}$ Geomat Geosci 1(2):179-187

Rastogi RA, Sharma TC (1976) Quantitative analysis of drainage basin characteristics. J Soil Water Conserv India 26(1-4):18-25

Reddy OGP, Maji AK, Gajbhiye SK (2004) Drainage morphometry and its influence on landform characteristics in a basaltic terrain, Central India-a remote sensing and GIS approach. Int J Appl Earth Obs Geoinformatics 6:1-16

Schumm SA (1956) Evolution of drainage systems and slopes in badlands at Perth Amboy, New Jersey. Geol Soc Am Bull 67:597-646

Schumm SA (1963) Sinuosity of alluvial rivers in the great plains. Bull Geol Soc Am 74:1089-1100

Sethupathi AS, Lakshmi Narasimhan C, Vasanthamohan V, Mohan SP (2011) Prioritization of mini watersheds based on morphometric analysis using remote sensing and GIS in a drought prone Bargur Mathur sub watersheds, Ponnaiyar River basin, India. Int J Geomat Geosci 2(2):403-414 
Shreve RW (1969) Stream lengths and basin areas in topologically random channel networks. J Geol 77:397-414

Singh KN (1980) Quantitative analysis of landfroms and settlement distribution in southern uplands of eastern Uttar Pradesh (India). Vimal Prakashan, Varanasi

Singh S (1992) Quantitative geomorphology of the drainage basin. In: Chouhan TS, Joshi KN (eds) Readings on remote sensing applications. Scientific Publishers, Jodhpur

Singh S (1995) Quantitative analysis of watershed geomorphology using remote sensing techniques. Ann Arid Zone 34(4): 243-251

Singh S, Singh MB (1997) Morphometric analysis of Kanhar river basin. Natl Geogr J India 43(1):31-43

Smith KG (1950) Standards for grading texture of erosional topography. Am J Sci 248:655-668

Smith B, Sandwell D (2003) Accuracy and resolution of shuttle radar topography mission data. Geophys Res Lett 30(9):20-21
Sreedevi PD, Subrahmanyam K, Shakeel A (2005) The significance of morphometric analysis for obtaining groundwater potential zones in a structurally controlled terrain. J Environ Geol 47(3):412-420

Strahelr AN (1952) Hypsometric (area-altitude) analysis of erosional topography. Bull Geol, Soc Am 63

Strahler AN (1957) Quantitative analysis of watershed geomorphology. Trans Am Geophys Union 38:913-920

Strahler AN (1964) Quantitative geomorphology of drainage basins and channelnetworks. In: Chow VT (ed) Handbook of applied hydrology. McGraw-Hill, New York, pp 439-476

Verstappen H (1983) The applied geomorphology. In: International Institute for Aerial Survey and Earth Science (ITC). Enschede

Vittala SS, Govindiah S, Honne Gowda H (2004) Morphometric analysis of sub-watersheds in the pawagada area of Tumkur district, South India, using remote sensing and GIS techniques. J Indian Soc Remote Sens 32(4):351-362 